\title{
Timing of synconvergent extension in NW Himalaya: New geochronological constraints from the Gianbul dome (SE Zanskar)
}

\author{
Martin Robyr†*, J ames M Mattinsonł and Bradley R Hacker \\ $\dagger$ Institut of Mineralogy and Geochemistry, University of Lausanne,CH-1015 Lausanne, SWITZERLAND \\ ‡ Geological Sciences, University of Cal ifornia, Santa Barbara, CA 93106-9630, USA \\ * To whom correspondence should be addressed. E-mail: martin.robyr@img.unil.ch
}

High-grade metamorphic rocks of the High Himalayan CrystallineZone (HHCZ) of Zanskar areexposed as a $50 \mathrm{~km}$ large dome along the Miyar and Gianbul valleys in the NW Himalaya of India. This Gianbul dome is cored by migmatitic paragneiss formed at peak conditions of $800^{\circ} \mathrm{C}$ and $8 \mathrm{kbar}$. This migmatitic core is symmetrically surrounded by rocks of the sillimanite, kyanite \pm staurolite, garnet, biotite, and chlorite mineral zones. The structural and metamorphic data from the Miyar-Gianbul Valley section reveal that thetectono-metamorphic evolution of the HHCZ in SE Zanskar is associated with a polyphase tectonic history involving converging nappestructures superimposed by opposite-directed extensional structures (Dèzes et al. 1999, Steck et al.1999, Robyr et al. 2002). The first tectonic event corresponds to an early phase of crustal thickening related to NE-directed movements. This phase most likely took place during Early to Middle Eocene, and it led to the creation of Shikar Beh nappe, thrusting toward the NE along the MiyarThrust and responsible for theprogrademetamorphic field gradient in the southern limb of the dome (Steck et al. 1999, Robyr et al. 2002). Beneath the MiyarThrust, partial melting, related to thisinitial phase, occurred at temperatures between 750 and $850^{\circ} \mathrm{C}$. In thenorthern limb of the dome, the Barrovian prograde metamorphism is the consequence of a second tectonic phase, associated with theSWdirected thrusting of the Nyimaling-Tsarap nappe. During this phase, someof the paragneissweremigmatized as a consequence of temperature up to ca. $800^{\circ} \mathrm{C}$ at depth down to ca. $40 \mathrm{~km}$ (Dèzes et al. 1999, Robyr et al. 2002). Geochronological data reveal that this SW-directed phase occurred between Middle Eocene and Late Oligocene (Vance and Harris 1999, Schlup et al. 2003). Following these crustal thickening events, exhumation and doming of the HHCZ high-grade rocks were controlled by extension along the north-dipping Zanskar Shear Zone, in the frontal part of the Nyimaling-Tsarap nappe, as well as by extension along the south-dipping Khanjar Shear Zone, in the southern limb of the Gianbul dome. Rapid synconvergence extension along both of these detachments induced a nearly isothermal decompression, resulting in a high-temperature/ lowpressuremetamorphic overprint.

New geochronological dating of monazites from various migmatites in the footwall of the Khanjar Shear Zone indicates that these rocks cooled below $\mathrm{T}=725^{\circ} \mathrm{C}$ at $26.6 \mathrm{Ma}$. On the other hand, geochronological dating of monazitesfrom an undeformed leucogranitic dykecross-cutting the extensional structures of the Kanjar Shear Zonereveals ages between 19.9 and 23.6Ma. These results consequently indicate that ductile shearing along the Khanjar Shear Zone ended by 23.6 Ma and that extension most likely initiated shortly before $26.6 \mathrm{Ma}$. In the Gianbul Valley, geochronological results from variousleucogranitic plutonsand dykes in the footwall of the Zanskar Shear Zone indicates that partial melting on the NE-half of the Gianbul dome occurred between 19.8Ma and 22.2 Ma (Dèzes et al. 1999). Partial melting in this part of the Himalayan range is collectively interpreted as the consequence of the rapid exhumation of the high grade metamorphic rocks along the Zanskar Shear Zone, in good agreement with the isothermal decompression revealed by the P-T data. On basis of these observations, it iscommonlyassumed that the onset of extension along the Zanskar Shear Zone was not significantly older than 22.2Ma. However, structural analysis and geometric modelling indicate that the exhumation of the migmatitic Gianbul dome occurred contemporaneously along both theKhanjar Shear Zoneand theZanskarShear Zone, mainly because of thelack of a major thrust between thetwo extensional shear zones. It consequently appears that the extension along the Zanskar Shear Zonehas to begin shortly before26.6 Ma. This age is in good agreement with the data from the northernmost part of the HHCZ of Zanskar where Vance and Harris (1999) indicatea rapid decompression in the H HCZ rocks of $4 \mathrm{kbar}$ at 25 $\mathrm{Ma}$ and where Inger (1998) demonstrates that ductile deformation along the Zanskar Shear Zone was ongoing at 26 Ma.

Thepetrographic and quantitativeP-T results for the Miyar section and for the Gianbul section provide information about the depth of burial of the studied samples, as well as about the thermal structure during the tectonic evolution of a complete transect across the Gianbul dome. On the other hand, the mapping and structural analysis of this transect constrain its kinematic evolution. These various data, together with the geochronological constraints, can be combined to propose a semi-quantitative reconstruction of the tectono-metamorphic evolution across the Gianbul dome (Figure1).

During the first opposite-directed crustal thickening phases, theH HCZ high graderocksweresubducted down to ca.30 $\mathrm{km}$ depth, where temperature up to $850^{\circ} \mathrm{C}$ triggered partial melting. Asa consequence, therelativelyhigh buoyancy of these low-dense and low-viscous migmatites counteracted the downward pulling forces exerted by the still subsiding lithosphere. From that moment, the migmatitic rocks of the $\mathrm{HHCZ}$ of Zanskar were squeezed by the compressive forces exerted by the ongoing collision and the backstop represented by the sedimentary series of the Tethyan Himalaya. The presence of two major thrust zones directly above this migmatitic zone induced a weakness in the upper crustfacilitatingtheexhumation of thesehigh-gradelow-viscosity migmatites. As a consequence, high grade rocks of the HHCZ of Zanskar have been forced to extrudein this part of therange, and eventually "pierced" through the Tethyan sedimentary cover as a large-scale dome structure. Once the onset of extension along these detachements is triggered, decompression drives partial melting, leading to the development of positive feedback between melting and decompression, and thus enhancing the rapid exhumation of these migmatites. Following this initial doming phase, further extension along the Zanskar Shear Zone associated with combined thrusting along the Main Central Thrust led to tectonically-controlled ductileextrusion of the H HCZtoward SW. 
References

Dèzes P, JC Vannay, A Steck, F Bussy and M Cosca. 1999. Synorogenic extension: quantitative constraints on the age and displacement of theZanskar Shear Zone (NW Himalayas). Geol SocAmer Bull 111: 364 374

Inger S. 1998. Timing of an extensional detachment during convergent orogeny: New Rb-Sr geochronological data from the Zanskar shear zone, northwestern Himalaya: Geology 26: 223-226

Robyr M, JC Vannay, JL Epard and A Steck. 2002. Thrusting, extension, and doming during the polyphase tectonometamorphic evolution of the
High Himalayan Crystalline Zone in NW India. J Asian Earth Sci 21: 221-239

Schlup M, A Carter, M Cosca and ASteck. 2003. Exhumation history of eastern Ladakh revealed by 40Ar/39Ar and fission-track ages: the Indus RiverTso Morari transect, NW Himalaya. J Geol Soc London 160: 385-399

Steck A, JL Epard and M Robyr. 1999. The NE-directed Shikar Beh Nappe: A major structure of the Higher Himalaya. Edogaegeol Helvetiae92: 239-250

Vance D and N Harris. 1999. Timing of prograde metamorphism in the Zanskar Himalaya. Geology 27: 395-398

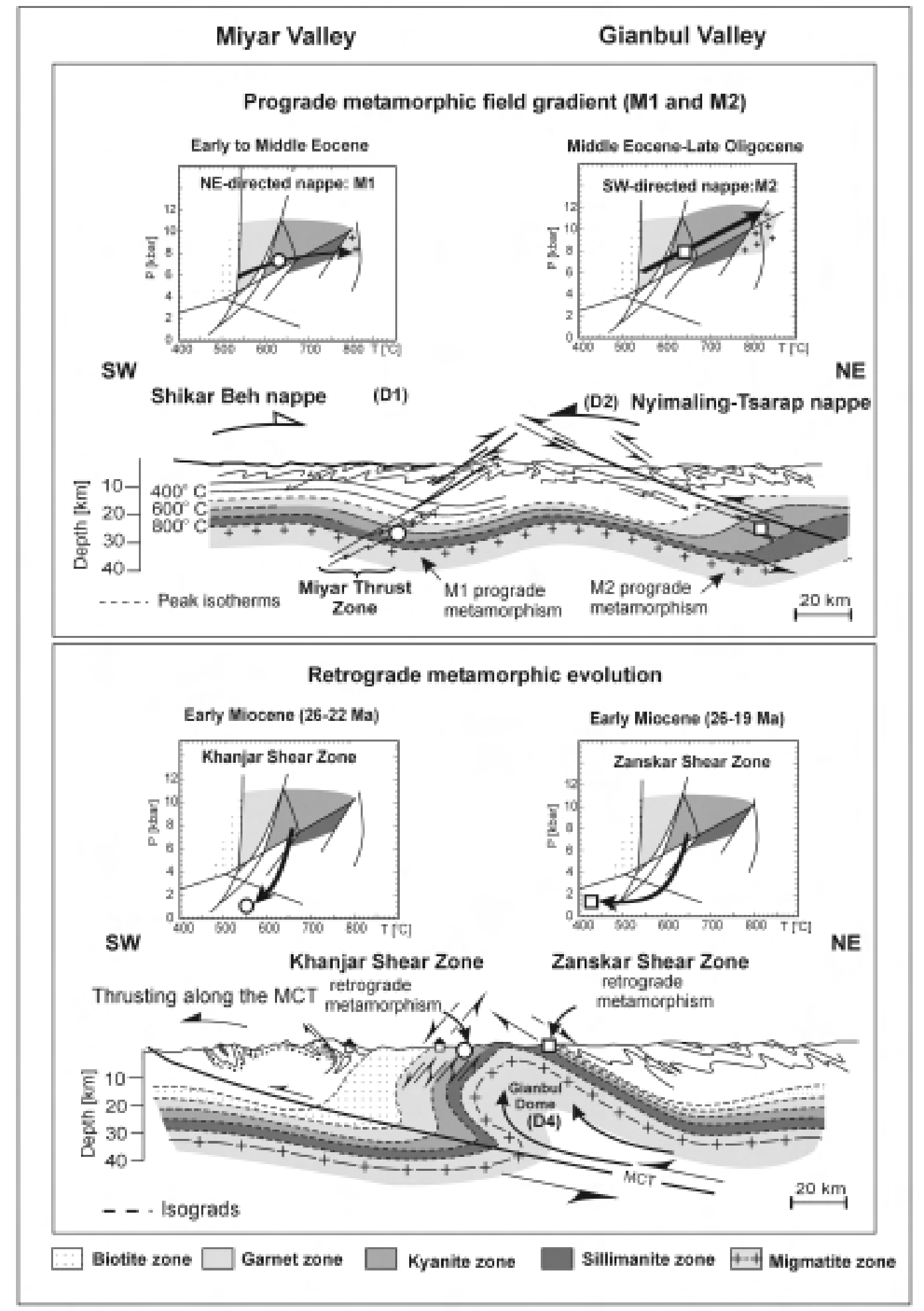

FIGURE 1. Semi-quantitative reconstruction of tectono-metamorphic evolution of the Gianbul dome 